\title{
Microwave assisted solventless synthesis of melamines with flexible aromatic substituents
}

\author{
Konstantin Doktorov, Vanya B. Kurteva,* Diana Ivanova, and Iliana Timtcheva \\ Institute of Organic Chemistry, Bulgarian Academy of Sciences, Acad. G. Bonchev str., bl. 9, \\ 1113 Sofia, Bulgaria \\ E-mail:vkurteva@orgchm.bas.bg
}

\begin{abstract}
A fast, highly efficient and environmentally friendly solvent-free procedure under microwave irradiation, using silica gel supported reagents for the synthesis of melamines with flexible aromatic $N$-substituents is developed. It is shown that both microwaves and silica gel accelerate the transformation studied. The synthetic approach presented herein has several advantages. It is a low cost protocol as using the cheap and easily available starting material, cyanuric chloride. The conversion is complete within $3 \mathrm{~min}$, which leads to a serious energy saving. Hydrogen chloride is the only by-product, which makes the procedure an atom economy benign. This byproduct is quenched as ammonium salts during the reaction, thus preventing its release into the environment.
\end{abstract}

Keywords: Melamines, aromatic substituents, microwaves, solid support, synthesis, absorption spectra

\section{Introduction}

The melamines, substituted 2,4,6-triamino-1,3,5-triazines, are an important class of organic compounds due to the broad variety of their applications: dendrimers, ${ }^{1,2}$ probes for circular dichroism, ${ }^{3-6}$ UV-filters, ${ }^{7-9}$ printing ink components, ${ }^{10-12}$ superstructure assemblies, ${ }^{13-20}$ etc. They have displayed a wide range of biological activity profiles, such as anti-tumour, ${ }^{21-24}$ treatments for menopausal symptoms and postmenopausal osteoporosis, ${ }^{25,26}$ anti-metastatic, ${ }^{27}$ antibacterial, $^{28-32}$ anti-inflammatory, ${ }^{33-35}$ herbicidal, ${ }^{36-39}$ etc. Nowadays, melamines with aromatic $N$-substituents have shown to be effective as HIV replication inhibitors and are clinically used for prevention and treatment of HIV infection. ${ }^{40-45}$

Microwave assisted reactions have become an established tool in organic synthesis, since they achieve rate enhancement, higher yields and better selectivity compared with conventional heating. ${ }^{46-52}$ The efficient, clean and economic solventless technique, ${ }^{53-57}$ which avoids hazards 
of solution phase reactions, where high pressures are created in a microwave oven at elevated temperatures, is an environmentally benign condition preventing release of reaction products into the environment.

Among the broad synthetic pathways, known for melamine preparation, ${ }^{58}$ an efficient and expedite method is based on the nucleophilic substitution of chlorine atoms in cyanuric chloride, a rather cheap and easily available material, with different amines. ${ }^{59-65}$ Recently, the microwave techniques have been applied and the transformation was achieved with significant rate enhancement and excellent conversion in solutions, ${ }^{66}$ solventless, ${ }^{67,68}$ and on solid supports ${ }^{69}$ as well.

An efficient atom economy and environmentally friendly solvent-free protocol for the synthesis of a series of melamines with flexible aromatic $\mathrm{N}$-substituents under microwave irradiation is presented herein.

\section{Results and Discussion}

The starting 2-chloro-4,6-dimorpholino-1,3,5-triazine (2) and 2,4-dichloro-6-morpholino-1,3,5triazine (10) were prepared by replacing the chlorine atoms in cyanuric chloride with morpholine, according to a known procedure. ${ }^{69,70}$ Morpholine was chosen as a non-aromatic amine due to the observed anti-inflammatory activity of similar melamines, ${ }^{35}$ which are described by the authors as "an aspirin of the $21^{\text {st }}$ century". The disubstituted product 2 was easily obtained by using morpholine both as a reagent and as a base, while in the case of $\mathbf{1 0}$ equimolar amounts of morpholine and carbonate as a base were used at $0^{\circ} \mathrm{C}$ to achieve the monosubstitution selectively. The target melamines were afterward obtained in a solventless protocol under microwave irradiation. Thus, mixtures of a chloride $\mathbf{2}$ or $\mathbf{1 0}$ and an aromatic amine, initially impregnated onto silica gel support by solvent removal of the preliminary prepared dichloromethane solutions, were irradiated in a domestic household microwave oven in open vessels with a power of $800 \mathrm{~W}$, to give the corresponding products 3-9 and 11-17, respectively, as shown on Scheme 1. 


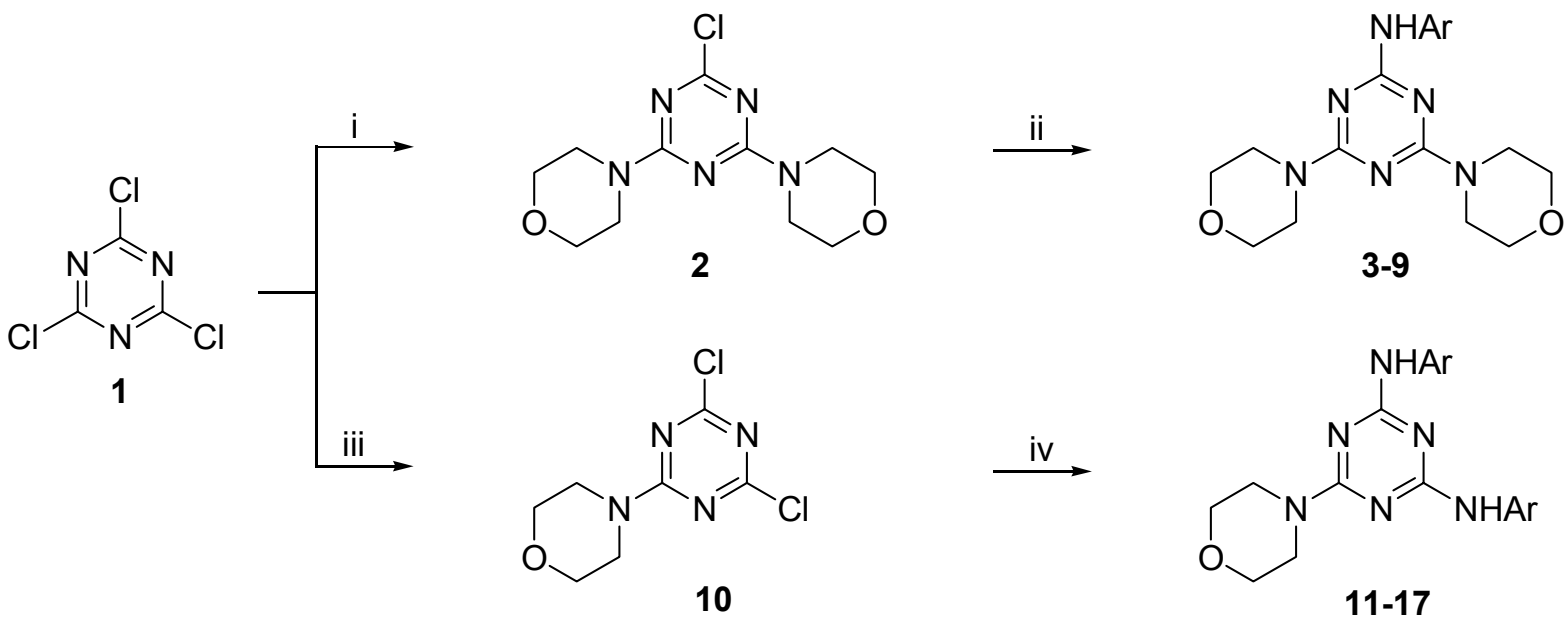

$\mathrm{Ar}=\mathrm{Ph}, 4-\mathrm{MePh}, 4-\mathrm{MeOPh}, 2-\mathrm{MeOPh}, 4-\mathrm{BrPh}, 4-\mathrm{CNPh}, 1$-naphthyl, 2-naphthyl

Scheme 1. Synthesis of compounds 2-17. i) morpholine (4 equiv), dichloromethane, rt; ii) $\mathrm{ArNH}_{2}$ (2 equiv), silica gel ( $\left.2 \mathrm{~g} / \mathrm{mmol}\right), \mathrm{MWI}, 800 \mathrm{~W}, 3 \mathrm{~min}$; iii) morpholine (1 equiv), $\mathrm{Na}_{2} \mathrm{CO}_{3}$ ( 1 equiv), dichloromethane, $0^{\circ} \mathrm{C}$; iv) $\mathrm{ArNH}_{2}$ (4 equiv), silica gel (2 g/mmol), MWI, $800 \mathrm{~W}$, 3 min.

The transformation proceeded very clean and fast. No side-product formation was detected. Complete conversion was observed within $3 \mathrm{~min}$ in all cases, which leads to a serious energy saving (Table 1). The products were isolated in excellent yields after a very simple work-up; the ammonium salt being filtered off together with the solid support. Analytical and fluorescent grade samples were obtained by purification on a high performance flash chromatography system.

Table 1. Synthesis of compounds 3-9 and 11-17: microwave irradiation; $800 \mathrm{~W} ; 3$ min

\begin{tabular}{lccccccc}
\hline Entry & Compd. & $\begin{array}{c}\text { Substituent } \\
\text { Ar }\end{array}$ & $\begin{array}{c}\text { Yield, } \\
\%\end{array}$ & Entry & Compd & $\begin{array}{c}\text { Substituent } \\
\text { Ar }\end{array}$ & $\begin{array}{c}\text { Yield, }^{a} \\
\%\end{array}$ \\
\hline 1 & $\mathbf{3}$ & $\mathrm{Ph}$ & 99 & 8 & $\mathbf{1 1}$ & $\mathrm{Ph}$ & 99 \\
2 & $\mathbf{4}$ & 4-MePh & 95 & 9 & $\mathbf{1 2}$ & 4-MePh & 96 \\
3 & $\mathbf{5}$ & 4-MeOPh & 99 & 10 & $\mathbf{1 3}$ & $4-\mathrm{MeOPh}$ & 98 \\
4 & $\mathbf{6}$ & 4-BrPh & 96 & 11 & $\mathbf{1 4}$ & 2-MeOPh & 99 \\
5 & $\mathbf{7}$ & 4-CNPh & 96 & 12 & $\mathbf{1 5}$ & 4-BrPh & 97 \\
6 & $\mathbf{8}$ & 1-naphthyl & 99 & 13 & $\mathbf{1 6}$ & 4-CNPh & 98 \\
7 & $\mathbf{9}$ & 2-naphthyl & 99 & 14 & $\mathbf{1 7}$ & 2-naphthyl & 98 \\
\hline
\end{tabular}

${ }^{a}$ After high performance flash chromatography purification.

The efficiency of the synthetic protocol does not depend on the bulk of the amine used and on the type of the substituents inside the series studied. As can be seen on Table 1, even the 
relatively hindered 1-naphthyl and 2-methoxyphenyl amines lead to quantitative isolated yields of the products 8 and 14, respectively (entries 6 and 11).

Silica gel was found be an effective solid support, while alumina oxides led to very slow conversion and side-products formation. The amount of the silica gel was optimized and was found that $2 \mathrm{~g}$ of per mmol of triazine is the best proportion.

The procedure presents an atom economy protocol as hydrogen chloride is the only byproduct of the reaction. This by-product was quantitatively quenched as ammonium salts during the reaction by the amine, used both as a nucleophile and as a base, thus preventing its release into the environment.

In order to study the role of the microwaves and of silica gel the formation of the melamine 4 was carried out in different reaction conditions, as shown on Table 2. The conversions were followed by ${ }^{1} \mathrm{H}$ NMR spectra of the crude reaction mixtures by comparing the integrals of the signals for $\mathrm{Ar}-\mathrm{CH}$ and $\mathrm{CH}_{3}$ protons of the product with those for morpholino groups, which appear as a common signal for $\mathbf{2}$ and $\mathbf{4}$.

Table 2. Synthesis of melamine $\mathbf{4}$ from $\mathbf{2}$ in different reaction conditions

\begin{tabular}{cccc}
\hline Entry & Reaction conditions & Time, min & Conversion, $\%^{\mathrm{a}}$ \\
\hline 1 & & 5 & 5 \\
2 & Thermal reaction in a decaline solution, $160^{\circ} \mathrm{C}^{\mathrm{b}}$ & 15 & 36 \\
3 & & 60 & 82 \\
4 & & 5 & 34 \\
5 & MW reaction in a decaline solution, $800 \mathrm{~W}^{\mathrm{b}, \mathrm{c}}$ & 15 & 61 \\
6 & & 5 & 17 \\
7 & Thermal reaction on silica gel, $160^{\circ} \mathrm{C}^{\mathrm{d}}$ & 15 & quantitative \\
8 & $\mathrm{MW}$ reaction on silica gel, $800 \mathrm{~W}^{\mathrm{d}, \mathrm{e}}$ & 3 & quantitative \\
\hline
\end{tabular}

${ }^{\mathrm{a}}$ Followed by ${ }^{1} \mathrm{H}$ NMR spectra of the crude reaction mixtures. ${ }^{\mathrm{b}}$ Concentration: $1 \mathrm{mmol} 2$ and 2 mmol amine in $5 \mathrm{ml}$ decaline. ${ }^{\mathrm{C}} \mathrm{A}$ temperature of $154{ }^{\circ} \mathrm{C}$ was measured at the end of the reaction. Proportions: $2 \mathrm{~g}$ silica gel per $1 \mathrm{mmol} 2$ and $2 \mathrm{mmol}$ amine. ${ }^{\mathrm{e}} \mathrm{A}$ temperature of $162{ }^{\circ} \mathrm{C}$ was measured at the end of the reaction.

Solutions of 2 and $p$-toluidine in decaline and mixtures of the same reagents initially impregnated on silica gel support were both irradiated in a microwave oven with a power of 800 $\mathrm{W}$ and heated conventionally at $160^{\circ} \mathrm{C}$. The latter is chosen on the basis of the temperatures measured at the end of the microwave reactions in decalin solution and on silica gel, $154^{\circ} \mathrm{C}$ and $162^{\circ} \mathrm{C}$, respectively. As can be seen on Table 2, considerable rate enhancement was observed in the presence of silica gel both under conventional heating and under microwave irradiation (entries 6,7 vs entries 1-3 and entry $8 v s$ entries 4,5), which is an indication that silica gel significantly promoted the reaction studied. On the other hand, the acceleration detected under microwave irradiation in comparison with the conventional heating in both cases (entries 4,5 vs 
entries 1-3 and entry $8 v s$ entries 6,7 ) demonstrates that microwaves assist the transformation as well.

The absorption spectra of the melamines were studied. All compounds absorb in ethanol at room temperature in the region $48000-30000 \mathrm{~cm}^{-1}$. It was observed that both electron donating substituents in $p$-position and prolongation of the conjugated system lead to a bathochromic shift with about $700 \mathrm{~cm}^{-1}$ of the longest wavelength absorption maximum (Figures 1 and Figure 2).

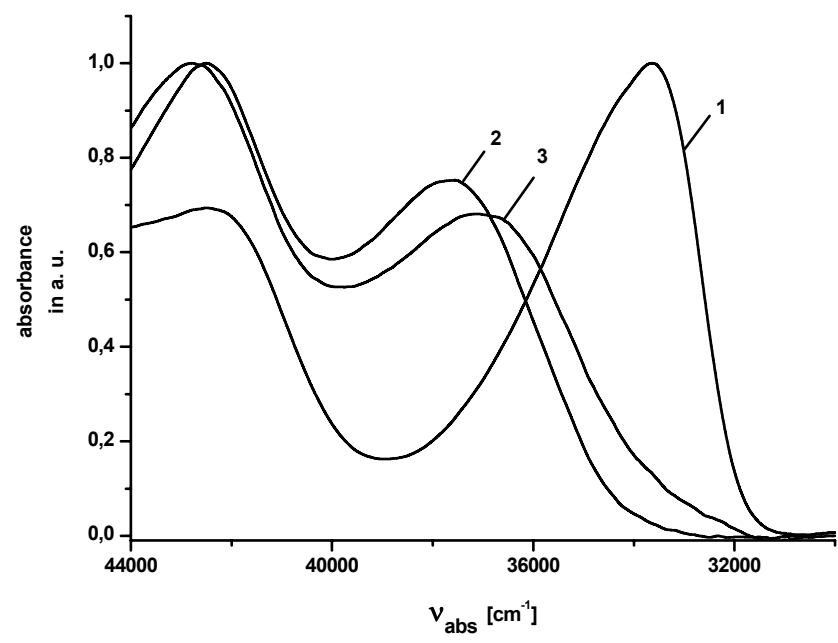

Figure 1. Absorption spectra in ethanol at room temperature of compounds: curve $1-\mathbf{7}$; curve 2 $\mathbf{- 3}$; curve $3-\mathbf{5}$.

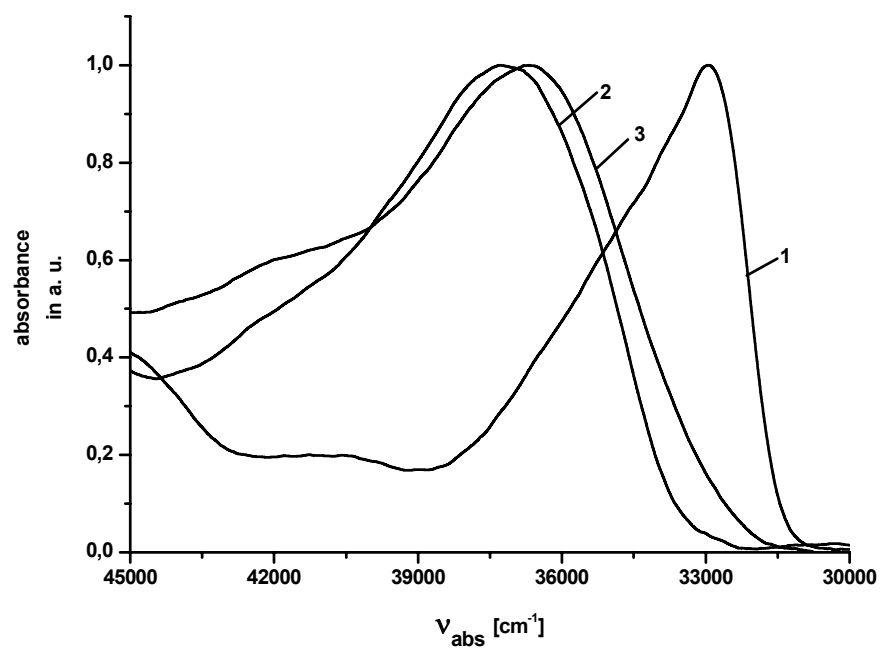

Figure 2. Absorption spectra in ethanol at room temperature of compounds: curve 1-16; curve 2 - 11; curve 3-13. 
A large red shift was detected in the case of $p$-CN-substituted compounds $\mathbf{7}$ and $\mathbf{1 6}$ (about $4000 \mathrm{~cm}^{-1}$ ) that could be explained by the occurrence of a strong charge transfer between the morpholine unit and cyano group. The investigated compounds do not fluorescence in solution at room temperature most probable due to a rotation around the single $\mathrm{C}-\mathrm{N}$ bond, which leads to radiationles deactivation of the first singlet excited state.

\section{Conclusions}

The microwave assisted solventless procedure, presented here, is a simple, fast, and highly effective method for the synthesis of melamines with flexible aromatic substituents. It is shown that both microwaves and silica gel accelerate the transformation studied. The conversion is complete within 3 min, which leads to a serious energy saving. The protocol presents an atom economy scheme as hydrogen chloride is the only by-product. The latter is quenched as an ammonium salt in the course of the reaction, thus avoiding its liberation into the air, which presents itself an additional environmentally benign synthetic advantage.

\section{Experimental Section}

General Procedures. All reagents were purchased from Aldrich, Merck and Fluka and were used without any further purification. Dichloromethane was dried over calcium hydride. The microwave irradiated reactions (MWI) were performed in domestic household oven Panasonic NN-S255W. Merck silica gel $60(0.040-0.063 \mathrm{~mm})$ was employed as a solid support. Fluka silica gel/TLC-cards 60778 with fluorescent indicator $254 \mathrm{~nm}$ were used for TLC chromatography and $\mathrm{R}_{\mathrm{f}}$-values determination. The purifications were carried out on a Biotage Horizon ${ }^{\mathrm{TM}}$ HPFC system on silica gel. The melting points were determined in capillary tubes on MEL-TEMP 1102D-230 VAC apparatus without corrections. The IR spectra were taken on a Bruker IFS 113v as $\mathrm{KBr}$ discs and were quoted in $\mathrm{cm}^{-1}$. The electronic spectra were scanned on a Lambda 25 (Perkin Elmer) UV-VIS spectrophotometer in ethanol; the energies of the absorption maxima (the longest wavelength absorption Franck-Condon transitions, $v_{\mathrm{abs}}$ ) were quoted in $\mathrm{cm}^{-1}$. The NMR spectra were recorded on a Bruker AVANCE DRX 250 spectrometer in deuterochloroform; the chemical shifts were quoted in ppm in $\delta$-values against tetramethylsilane (TMS) as an internal standard and the coupling constants were calculated in Hz. The low resolution mass spectra were taken on a HP 5973 Mass Selective Detector. The microanalyses were carried out by the microanalyses service of the Institute of Organic Chemistry, Bulgarian Academy of Sciences. 
Synthesis of the starting chlorotriazines 2 and 10

2,4-Bis(morpholino)-6-chloro-1,3,5-triazine (2) ${ }^{71}$ was prepared according to a literature procedure. $^{69}$

2,4-Dichloro-6-morpholino-1,3,5-triazine (10). ${ }^{72}$ To a solution of cyanuric chloride (10 mmol) in dry dichloromethane $(100 \mathrm{ml}) \mathrm{Na}_{2} \mathrm{CO}_{3}(10 \mathrm{mmol})$ and then morpholine $(10 \mathrm{mmol})$ were added and the mixture was stirred at $0^{\circ} \mathrm{C}$ for $1 \mathrm{~h}$. The solid phase was filtered off and was washed with dichloromethane. The solvent was removed in vacuo: $73 \%$ yield; $\mathrm{R}_{\mathrm{f}} 0.31$ (ether:hexane 1:3); $\mathrm{m}$. p. $155-158^{\circ} \mathrm{C}$ (lit. $^{72} 157.5-158.5^{\circ} \mathrm{C}$ ); IR 536.3, 791.5, 838.6, 847.5, 994.0, 1114.8, 1162.9, $1231.3,1241.2,1361.4,1384.8,1442.5,1481.2,1558.4,1587.6,2862.6,2924.4,2971.2 ;{ }^{1} \mathrm{H}$ NMR 3.753 (m, 4H, morpholine), 3.892 (m, 4H, morpholine); ${ }^{13} \mathrm{C}$ NMR $44.31\left(\mathrm{CH}_{2}-\mathrm{N}\right), 66.19$ $\left(\mathrm{CH}_{2}-\mathrm{O}\right), 163.93\left(C_{\text {quat }}-\mathrm{N}\right), 170.25\left(C_{\text {quat }}-\mathrm{Cl}\right)$.

\section{Synthesis of melamines 3-9. General procedure}

To a solution of chloro triazine 2 (1 mmol) in dichloromethane $(5 \mathrm{ml})$ an aromatic amine $(2$ $\mathrm{mmol})$ and then silica gel $(2 \mathrm{~g})$ were added. The solvent was removed in vacuo and the mixture was irradiated in a microwave oven with a power of $800 \mathrm{~W}$ for $3 \mathrm{~min}$. The products were purified by high performance flash chromatography on silica gel (1:50). The yields of the products 3-9 are summarized on Table 1.

Melamine 3. ${ }^{73}$ Flash chromatography $\left(\mathrm{CH}_{2} \mathrm{Cl}_{2}: \mathrm{MeOH} \quad 100: 1\right), \mathrm{R}_{\mathrm{f}} \quad 0.25 ;$ m.p. $164-166^{\circ} \mathrm{C}$ (lit. ${ }^{73} 168-169^{\circ} \mathrm{C}$ ); IR 507.4, 532.6, 545.0, 570.7, 689.4, 751.9, 804.1, 863.8, 920.3, 1008.6, $1110.9,1258.0,1287.4,1360.2$, 1439.6, 1476.1, 1510.0, 1541.6, 1578.7, 1613.7, 2844.9, 2894.8, 2921.6, 2946.8, 2963.0, 2983.3, 3361.6; UV 38020; ${ }^{1} \mathrm{H}$ NMR 3.726 (m, 8H, morpholine), 3.777 (m, 8H, morpholine), 7.021 (t, 1H, J 7.3, CH-4 of Ar), 7.286 (dd, 2H, J 1.9, 7.5, CH-3 and CH-5 of $\mathrm{Ar}), 7.538$ (d, 2H, J 7.7, $\mathrm{CH}-2$ and $\mathrm{CH}-6$ of $\mathrm{Ar}) ;{ }^{13} \mathrm{C} \mathrm{NMR} 43.62\left(\mathrm{CH}_{2}-\mathrm{N}\right), 66.75\left(\mathrm{CH}_{2}-\mathrm{O}\right)$, $119.63(\mathrm{CH}-2$ and $\mathrm{CH}-6$ of Ar), 122.31 ( $\mathrm{CH}-4$ of Ar), $128.65(\mathrm{CH}-3$ and $\mathrm{CH}-5$ of $\mathrm{Ar}), 139.37$ $\left(C_{\text {quat }}, C-1\right.$ of $\left.\mathrm{Ar}\right), 164.30\left(C_{\text {quat }}-\mathrm{NH}\right), 165.17\left(C_{\text {quat }} \mathrm{N}\right)$; MS $(\mathrm{EI}+) \mathrm{m} / \mathrm{z} 342\left(\mathrm{M}^{+}, 100\right), 325(17)$, 312 (85), 297 (64), 285 (71), 281 (22), 267 (32), 255 (23), 144 (23), 118 (15), 77 (21), 69 (11), $56(13)$.

Melamine 4. Flash chromatography $\left(\mathrm{CH}_{2} \mathrm{Cl}_{2}: \mathrm{MeOH} 100: 1\right), \mathrm{R}_{\mathrm{f}} 0.25 ; \mathrm{m}$. p. 195-198 ${ }^{\circ} \mathrm{C}$; IR 508.6, 548.4, 597.6, 635.0, 649.0, 737.8, 803.8, 865.9, 920.4, 1009.4, 1110.8, 1259.1, 1286.3, 1305.3, 1360.0, 1416.8, 1445.9, 1474.9, 1509.1, 1545.1, 1609.5, 2845.3, 2894.7, 2945.7, 2964.0, 2981.4, 3362.6; UV 37310; ${ }^{1} \mathrm{H}$ NMR 2.308 (s, 3H, $\mathrm{CH}_{3}$ ), 3.725 (m, 8H, morpholine), 3.768 (m, 8H, morpholine), 6.808 (bs, 1H, NH), 7.106 (d, 2H, J 8.3, CH-3 and $\mathrm{CH}-5$ of Ar), 7.409 (dd, 2H, J 1.6, 8.3, $\mathrm{CH}-2$ and $\mathrm{CH}-6$ of Ar); ${ }^{13} \mathrm{C}$ NMR $20.72\left(\mathrm{CH}_{3}\right), 43.70\left(\mathrm{CH}_{2}-\mathrm{N}\right), 66.75\left(\mathrm{CH}_{2}-\mathrm{O}\right), 119.99$ $\left(\mathrm{CH}-2\right.$ and $\mathrm{CH}-6$ of Ar), $129.20\left(\mathrm{CH}-3\right.$ and $\mathrm{CH}-5$ of Ar), 131.87 ( $C_{\text {quat }}, C-4$ of Ar), 136.71 ( $C_{\text {quat }}$, $C$-1 of Ar), $164.33\left(C_{\text {quat }}-\mathrm{NH}\right), 165.21\left(C_{\text {quat }}-\mathrm{N}\right)$; MS (EI+) m/z $356\left(\mathrm{M}^{+}, 100\right), 339(6), 326(56)$, 311 (52), 299 (57), 295 (17), 281 (25), 269 (17), 158 (18), 91 (15), 86 (21), 77 (3), 69 (7), 56 (10).

Melamine 5. Flash chromatography $\left(\mathrm{CH}_{2} \mathrm{Cl}_{2}: \mathrm{MeOH} 100: 1\right), \mathrm{R}_{\mathrm{f}} 0.22 ; \mathrm{m}$. p. 202-203 ${ }^{\circ} \mathrm{C}$; IR 441.6, 518.8, 543.3, 557.3, 593.7, 637.3, 801.8, 822.9, 865.0, 918.0, 1008.8, 1109.6, 1228.6, 1253.6, 
1286.3, 1309.3, 1360.2, 1423.1, 1476.2, 1510.3, 1548.9, 1606.0, 2849.6, 2866.3, 2896.6, 2946.6, 2960.2, 2980.6, 2994.9, 3380.8; UV 37040; ${ }^{1} \mathrm{H}$ NMR 3.706 (m, 8H, morpholine), 3.770 (m, 8H, morpholine), 3.792 (s, $3 \mathrm{H}, \mathrm{OCH}_{3}$ ), 6.855 (dd, $2 \mathrm{H}, \mathrm{J} 2.2,6.8, \mathrm{CH}-3$ and $\mathrm{CH}-5$ of Ar), 7.422 (dd, $2 \mathrm{H}, \mathrm{J} 2.2,6.8, \mathrm{CH}-2$ and $\mathrm{CH}-6$ of $\mathrm{Ar}) ;{ }^{13} \mathrm{C}$ NMR $43.71\left(\mathrm{CH}_{2}-\mathrm{N}\right), 55.50\left(\mathrm{OCH}_{3}\right), 66.84\left(\mathrm{CH}_{2}-\mathrm{O}\right)$, $113.97(\mathrm{CH}-3$ and $\mathrm{CH}-5$ of $\mathrm{Ar}), 121.76\left(\mathrm{CH}-2\right.$ and $\mathrm{CH}-6$ of Ar), $132.52\left(\mathrm{C}_{\text {quat }}, \mathrm{CH}-1\right.$ of Ar$)$, $155.36\left(C_{\text {quat }}, C \mathrm{H}-4\right.$ of $\left.\mathrm{Ar}\right), 164.50\left(C_{\text {quat }}-\mathrm{NH}\right), 165.32\left(C_{\text {quat }} \mathrm{-N}\right)$; MS $(\mathrm{EI}+) \mathrm{m} / \mathrm{z} 372\left(\mathrm{M}^{+}, 100\right)$, 357 (10), 341 (35), 327 (40), 315 (44), 311 (11), 297 (19), 285 (12), 174 (9), 148 (8), 133 (10), 94 (3), 69 (7), 56 (7).

Melamine 6. Flash chromatography $\left(\mathrm{CH}_{2} \mathrm{Cl}_{2}: \mathrm{MeOH} 100: 1\right)$, $\mathrm{R}_{\mathrm{f}} 0.28$; m. p. $225-227^{\circ} \mathrm{C}$; IR 463.4, 504.3, 543.9, 581.9, 623.2, 803.7, 823.5, 862.8, 920.0, 1006.7, 1066.6, 1107.4, 1227.3, 1255.2, 1280.2, 1302.3, 1360.2, 1400.7, 1443.7, 1488.8, 1525.7, 1573.9, 1601.9, 2853.7, 2890.1, 2966.4, 2990.4, 3106.3, 3403.0; UV 36360; ${ }^{1} \mathrm{H}$ NMR 3.722 (m, 8H, morpholine), 3.773 (m, 8H, morpholine), $6.921(\mathrm{bs}, 1 \mathrm{H}, \mathrm{NH}), 7.412(\mathrm{~m}, 4 \mathrm{H}, \mathrm{CH}$ of $\mathrm{Ar}) ;{ }^{13} \mathrm{C}$ NMR $43.70\left(\mathrm{CH}_{2}-\mathrm{N}\right), 66.73$ $\left(\mathrm{CH}_{2}-\mathrm{O}\right), 114.84$ ( $\mathrm{C}_{\text {quat }}, \mathrm{CH}-4$ of $\left.\mathrm{Ar}\right), 121.30(\mathrm{CH}-2$ and $\mathrm{CH}-6$ of $\mathrm{Ar}), 131.59(\mathrm{CH}-3$ and $\mathrm{CH}-5$ of $\mathrm{Ar}), 138.33\left(C_{\text {quat }}, \mathrm{CH}-1\right.$ of $\left.\mathrm{Ar}\right), 164.19\left(C_{\text {quat }}-\mathrm{NH}\right), 165.08\left(C_{\text {quat }}-\mathrm{N}\right) ; \mathrm{MS}(\mathrm{EI}+) \mathrm{m} / \mathrm{z} 422\left(\mathrm{M}^{+}\right.$, 100), 420 ( $\left.\mathrm{M}^{+}, 97\right), 405$ (8), 403 (8), 392 (82), 390 (80), 377 (77), 375 (54), 365 (60), 363 (65), 347 (30), 345 (27), 341 (16), 335 (25), 333 (26), 319 (12), 305 (17), 224 (16), 222 (15), 198 (18), 196 (25), 157 (10), 155 (9), 138 (11), 113 (18), 86 (17), 84 (15), 81 (9), 79 (9), 69 (20), 56 (24).

Melamine 7. Flash chromatography $\left(\mathrm{CH}_{2} \mathrm{Cl}_{2}: \mathrm{MeOH} 100: 1\right), \mathrm{R}_{\mathrm{f}} 0.26$; m. p. $243-247^{\circ} \mathrm{C}$; IR 545.8, 590.1, 636.4, 653.3, 714.4, 742.0, 805.4, 837.1, 864.0, 918.0, 1028.7, 1112.3, 1174.4, 1251.9, 1300.1, 1360.4, 1394.1, 1411.3, 1450.7, 1474.0, 1504.5, 1530.4, 1574.2, 1614.9, 2217.7, 2863.8, 2900.5, 2963.2, 2989.0, 2999.7, 3198.8, 3307.0; UV 32260; ${ }^{1} \mathrm{H}$ NMR 3.747 (m, 16H, morpholine), 7.026 (bs, 1H, NH), 7.568 (dd, 2H, J 2.0, 8.9, Ar), 7.661 (dd, 2H, J 2.1, 8.9, Ar); ${ }^{13} \mathrm{C}$ NMR $43.71\left(\mathrm{CH}_{2}-\mathrm{N}\right), 66.70\left(\mathrm{CH}_{2}-\mathrm{O}\right), 104.60\left(C_{\text {quat }}, \mathrm{CH}-4\right.$ of $\left.\mathrm{Ar}\right), 118.92(\mathrm{CH}-2$ and $\mathrm{CH}-6$ of $\mathrm{Ar}), 119.30\left(C_{\text {quat }}, \mathrm{CN}\right), 133.06(\mathrm{CH}-3$ and $\mathrm{CH}-5$ of $\mathrm{Ar}), 143.56\left(C_{\text {quat }}, \mathrm{CH}-1\right.$ of $\left.\mathrm{Ar}\right), 163.86$ $\left(C_{\text {quat }} \mathrm{NH}\right), 164.95\left(C_{\text {quat }} \mathrm{N}\right)$; MS (EI+) m/z $367\left(\mathrm{M}^{+}, 100\right), 350(8), 337$ (82), 335 (70), 324 (34), 322 (58), 310 (71), 306 (23), 292 (34), 280 (26), 265 (10), 252 (15), 228 (13), 169 (26), 156 (6), 143 (14), 113 (9), 102 (12), 94 (7), 86 (11), 69 (12), 56 (14).

Melamine 8. Flash chromatography $\left(\mathrm{CH}_{2} \mathrm{Cl}_{2}: \mathrm{MeOH} 100: 1\right), \mathrm{R}_{\mathrm{f}} 0.19 ; \mathrm{m} . \mathrm{p} .160-162^{\circ} \mathrm{C}$; IR 537.7, 543.6, 777.2, 805.6, 841.3, 918.8, 1006.1, 1021.6, 1069.4, 1112.5, 1257.8, 1359.8, 1391.0, 1437.0, 1494.1, 1510.8, 1531.7, 1590.5, 2853.2, 2892.8, 2962.4, 3051.4, 3295.3; ${ }^{1} \mathrm{H}$ NMR 3.686 (m, 8H, morpholine), $3.738(\mathrm{~m}, 8 \mathrm{H}$, morpholine), $7.134(\mathrm{bs}, 1 \mathrm{H}, \mathrm{NH}), 7.456(\mathrm{~m}, 3 \mathrm{H}, \mathrm{CH}$ of naphthyl), 7.617 (d, 1H, J 8.2, $\mathrm{CH}$ of naphthyl), 7.835 (m, 1H, $\mathrm{CH}$ of naphthyl), 7.985 (m, 2H, $\mathrm{CH}$ of naphthyl); ${ }^{13} \mathrm{C}$ NMR $43.68\left(\mathrm{CH}_{2}-\mathrm{N}\right), 66.84\left(\mathrm{CH}_{2}-\mathrm{O}\right), 119.72(\mathrm{CH}$ of naphthyl), 121.46 ( $\mathrm{CH}$ of naphthyl), 124.06 ( $\mathrm{CH}$ of naphthyl), 125.55 ( $\mathrm{CH}$ of naphthyl), 125.70 ( $\mathrm{CH}$ of naphthyl), $125.76\left(\mathrm{CH}\right.$ of naphthyl), 127.35 ( $C_{\text {quat }}$ of naphthyl), 128.55 ( $\mathrm{CH}$ of naphthyl), 134.17 ( $C_{\text {quat }}$ of naphthyl), 134.18 ( $C_{\text {quat }}$ of naphthyl), $165.31\left(C_{\text {quat }}-\mathrm{NH}\right), 165.42\left(C_{\text {quat }}-\mathrm{N}\right)$.

Melamine 9. Flash chromatography $\left(\mathrm{CH}_{2} \mathrm{Cl}_{2}: \mathrm{MeOH} 100: 1\right), \mathrm{R}_{\mathrm{f}} 0.35$; m. p. $236-238^{\circ} \mathrm{C}$; IR 474.4, 546.9, 749.7, 804.1, 857.9, 1008.6, 1111.1, 1222.2, 1257.5, 1287.7, 1364.2, 1404.6, 1434.2, 1495.7, 1517.6, 1576.9, 1599.5, 2853.6, 2891.4, 2964.6, 2991.0, 3049.4, 3372.4; UV 35710, 
33330; ${ }^{1} \mathrm{H}$ NMR 3.753 (m, 8H, morpholine), 3.836 (m, 8H, morpholine), 7.117 (bs, 1H, NH), 7.328-7.474 (m, 2H, CH-6 and CH-7 of naphthyl), 7.565 (dd, 1H, J 2.2, 8.9, CH-3 of naphthyl), 7.713 (d, 1H, J 8.1, CH-4 of naphthyl), 7.768 (d, 2H, J 8.8, CH-5 and CH-8 of naphthyl), 8.133 (d, 1H, J 2.0, CH-1 of naphthyl); ${ }^{13} \mathrm{C}$ NMR $43.74\left(\mathrm{CH}_{2}-\mathrm{N}\right), 66.78\left(\mathrm{CH}_{2}-\mathrm{O}\right), 115.86(\mathrm{CH}$ of naphthyl), 120.71 ( $\mathrm{CH}$ of naphthyl), 124.30 ( $\mathrm{CH}$ of naphthyl), 126.31 ( $\mathrm{CH}$ of naphthyl), 127.17 ( $C H$ of naphthyl), 127.53 ( $C H$ of naphthyl), 128.31 ( $C H$ of naphthyl), 129.75 ( $C_{\text {quat }}$ of naphthyl), $133.89\left(C_{\text {quat }}\right.$ of naphthyl), $136.76\left(C_{\text {quat }}\right.$ of naphthyl), $164.37\left(C_{\text {quat }}-\mathrm{NH}\right), 165.14\left(C_{\text {quat }}-\mathrm{N}\right)$; MS (EI+) m/z $392\left(\mathrm{M}^{+}, 100\right), 375$ (3), 362 (48), 360 (44), 347 (43), 335 (51), 331 (16), 317 (22), 305 (15), 277 (10), 248 (9), 221 (10), 194 (20), 181 (8), 168 (26), 153 (8), 141 (9), 127 (28), 115 (16), 94 (7), 86 (4), 77 (3), 69 (12), 56 (19).

Synthesis of melamines 11-17. General procedure. To a solution of dichloro triazine 10 (1 $\mathrm{mmol})$ in dichloromethane $(5 \mathrm{ml})$ an aromatic amine $(4 \mathrm{mmol})$ and then silica gel $(2 \mathrm{~g})$ were added. The solvent was removed in vacuo and the mixture was irradiated in a microwave oven with a power of $800 \mathrm{~W}$ for $3 \mathrm{~min}$. The products were purified by high performance flash chromatography on silica gel (1:50). The yields of the products 11-17 are summarized on Table 1 .

Melamine 11. Flash chromatography $\left(\mathrm{CH}_{2} \mathrm{Cl}_{2}: \mathrm{MeOH}: \mathrm{NH}_{4} \mathrm{OH}\right.$ 100:1:0.1), $\mathrm{R}_{\mathrm{f}}$ 0.23; m. p. 190$191{ }^{\circ} \mathrm{C}$; IR 502.9, 705.9, 761.7, 806.4, 893.8, 1024.6, 1106.3, 1218.9, 1265.7, 1291.0, 1414.5, $1437.9,1503.7,1537.5,1578.8,1591.6,1611.6,2854.0,2960.2,2976.5,3315.6,3393.1$; UV 37740; ${ }^{1} \mathrm{H}$ NMR 3.732 (m, 4H, morpholine), 3.824 (m, 4H, morpholine), 7.038 (t, 2H, J 7.4, CH4 of Ar), 7.132 (bs,2H,NH), 7.302 (dd, 4H, J 7.5, 8.3, CH-3 and CH-5 of Ar), 7.532 (d, 4H, J 8.3, $\mathrm{CH}-2$ and $\mathrm{CH}-6$ of $\mathrm{Ar}) ;{ }^{13} \mathrm{C} \mathrm{NMR} 43.80\left(\mathrm{CH}_{2}-\mathrm{N}\right), 66.75\left(\mathrm{CH}_{2}-\mathrm{O}\right), 120.23(\mathrm{CH}-2$ and $\mathrm{CH}-6$ of $\mathrm{Ar}), 122.89$ (CH-4 of Ar), 128.74 (CH-3 and $\mathrm{CH}-5$ of $\mathrm{Ar}), 138.92$ ( $C_{\text {quat }}, \mathrm{CH}-1$ of $\left.\mathrm{Ar}\right), 164.34$ $\left(C_{\text {quat }}-\mathrm{NH}\right), 165.25\left(C_{\text {quat }}-\mathrm{N}\right)$; MS (EI+) m/z $506\left(\mathrm{M}^{+}, 100\right), 331$ (5), 317 (61), 303 (76), 291 (60), 262 (38), 235 (15), 227 (16), 220 (27), 199 (9), 185 (11), 159 (11), 144 (42), 131 (10), 118 (36), 92 (19), 77 (73), 65 (19), 56 (18).

Melamine 12. Flash chromatography $\left(\mathrm{CH}_{2} \mathrm{Cl}_{2}: \mathrm{MeOH}: \mathrm{NH}_{4} \mathrm{OH}\right.$ 100:1:0.1), $\mathrm{R}_{\mathrm{f}}$ 0.47; m. p. 247$249^{\circ} \mathrm{C}$; IR 504.5, 806.1, 816.3, 900.2, 1026.9, 1118.2, 1227.8, 1271.1, 1306.7, 1415.0, 1442.6, $1495.4,1519.8,1557.5,1579.8,1593.1,2853.8,2894.0,2916.8,2950.5,2958.8,3318.9$; UV 37040; ${ }^{1} \mathrm{H}$ NMR 2.326 (s, 6H, CH $), 3.730$ (m, 4H, morpholine), 3.838 (m, 4H, morpholine), 7.127 (d, 4H, J 8.3, CH-3 and $\mathrm{CH}-5$ of Ar), 7.413 (d, 4H, J 8.3, $\mathrm{CH}-2$ and $\mathrm{CH}-6$ of Ar), 7.850 (bs, 2H, NH); ${ }^{13} \mathrm{C}$ NMR $20.42\left(\mathrm{CH}_{3}\right), 43.42\left(\mathrm{CH}_{2}-\mathrm{N}\right), 66.03\left(\mathrm{CH}_{2}-\mathrm{O}\right), 120.07(\mathrm{CH}-2$ and $\mathrm{CH}-6$ of $\mathrm{Ar}), 128.79$ ( $\mathrm{CH}-3$ and $C \mathrm{H}-5$ of $\mathrm{Ar}), 130.57$ ( $C_{\text {quat }}, C-4$ of $\left.\mathrm{Ar}\right), 137.57$ ( $C_{\text {quat }}, C-1$ of $\left.\mathrm{Ar}\right), 164.04$ $\left(C_{\text {quat }}-\mathrm{NH}\right), 164.72\left(C_{\text {quat }} \mathrm{N}\right)$; MS (EI+) m/z $376\left(\mathrm{M}^{+}, 100\right), 359$ (5), 345 (51), 331 (64), 319 (52), 290 (25), 248 (18), 241 (13), 158 (24), 145 (6), 131 (18), 106 (13), 91 (22), 77 (8), 65 (7), 56 (4).

Melamine 13. Flash chromatography $\left(\mathrm{CH}_{2} \mathrm{Cl}_{2}: \mathrm{MeOH} 100: 1\right), \mathrm{R}_{\mathrm{f}} 0.29 ; \mathrm{m}$. p. $182-183^{\circ} \mathrm{C}$; IR 569.9, 803.5, 824.2, 899.6, 1027.4, 1107.8, 1241.7, 1298.8, 1417.9, 1512.4, 1566.4, 1596.5, 2830.6, 2856.9, 2902.8, 2940.3, 2954.2, 2994.4, 3295.1; UV 36360; ${ }^{1} \mathrm{H}$ NMR 3.714 (m, 4H, morpholine), 3.769 (m, 4H, morpholine), 3.793 (s, 6H, OCH $), 6.850$ (d, 4H, J 9.0, CH-3 and 
$\mathrm{CH}-5$ of Ar), 6.929 (bs, 2H, NH), 7.412 (d, 4H, J 9.0, $\mathrm{CH}-2$ and $\mathrm{CH}-6$ of Ar); ${ }^{13} \mathrm{C}$ NMR 43.73 $\left(\mathrm{CH}_{2}-\mathrm{N}\right), 55.49\left(\mathrm{OCH}_{3}\right), 66.78\left(\mathrm{CH}_{2}-\mathrm{O}\right), 113.96(\mathrm{CH}-3$ and $\mathrm{CH}-5$ of $\mathrm{Ar}), 122.28(\mathrm{CH}-2$ and $\mathrm{CH}-$ 6 of $\mathrm{Ar}), 132.02$ ( $C_{\text {quat }}, \mathrm{CH}-1$ of Ar), $155.64\left(C_{\text {quat }}, \mathrm{CH}-4\right.$ of $\left.\mathrm{Ar}\right), 164.46\left(C_{\text {quat }}-\mathrm{NH}\right), 165.27$ $\left(C_{\text {quat }} \mathrm{N}\right) ; \mathrm{MS}(\mathrm{EI}+) \mathrm{m} / \mathrm{z} 408\left(\mathrm{M}^{+}, 100\right), 393$ (29), 377 (31), 363 (48), 351 (35), 322 (12), 280 (9), 257 (10), 204 (9), 174 (16), 148 (13), 133 (17), 122 (10), 108 (9), 94 (3), 77 (4), 69 (6), 56 (6).

Melamine 14. Flash chromatography $\left(\mathrm{CH}_{2} \mathrm{Cl}_{2}: \mathrm{MeOH}: \mathrm{NH}_{4} \mathrm{OH}\right.$ 100:1:0.1), $\mathrm{R}_{\mathrm{f}}$ 0.35; m.p. 201$203^{\circ} \mathrm{C}$; IR 594.4, 751.3, 801.8, 1025.6, 1115.2, 1241.3, 1276.2, 1429.3, 1458.0, 1477.9, 1512.0, 1582.1, 1615.4, 2851.2, 2959.5, 3420.1, 3432.1; UV 37310, 33330; ${ }^{1} \mathrm{H}$ NMR 3.772 (m, 4H, morpholine), 3.875 (m, 4H, morpholine), $3.896\left(\mathrm{~s}, 6 \mathrm{H}, \mathrm{OCH}_{3}\right), 6.895$ (m, 2H, $\mathrm{CH}$ of Ar), 6.988 (m, $4 \mathrm{H}, \mathrm{CH}$ of Ar), $7.430(\mathrm{bs}, 2 \mathrm{H}, \mathrm{NH}), 8.425(\mathrm{~m}, 2 \mathrm{H}, \mathrm{CH}$ of $\mathrm{Ar}) ;{ }^{13} \mathrm{C}$ NMR $43.82\left(\mathrm{CH}_{2}-\mathrm{N}\right)$, $55.60\left(\mathrm{OCH}_{3}\right), 66.81\left(\mathrm{CH}_{2}-\mathrm{O}\right), 109.94(\mathrm{CH}$ of $\mathrm{Ar}), 119.81(\mathrm{CH}$ of $\mathrm{Ar}), 120.58(\mathrm{CH}$ of $\mathrm{Ar})$, $122.04\left(C \mathrm{H}\right.$ of Ar),128.71 ( $C_{\text {quat }}, C \mathrm{H}-1$ of $\left.\mathrm{Ar}\right), 148.07\left(C_{\text {quat }}, \mathrm{CH}-2\right.$ of $\left.\mathrm{Ar}\right), 164.19\left(C_{\text {quat }}-\mathrm{NH}\right)$, $165.33\left(C_{\text {quat }} \mathrm{N}\right)$ ) MS (EI+) m/z $408\left(\mathrm{M}^{+}, 22\right), 377$ (100), 363 (6), 351 (8), 347 (15), 159 (9), 105 (10), 92 (5), 77 (6), 65 (4), 56 (7).

Melamine 15. Flash chromatography $\left(\mathrm{CH}_{2} \mathrm{Cl}_{2}: \mathrm{MeOH}: \mathrm{NH}_{4} \mathrm{OH}\right.$ 200:0.5:0.1), $\mathrm{R}_{\mathrm{f}}$ 0.35; m.p. 289$290^{\circ} \mathrm{C}$; IR 501.5, 568.1, 804.7, 820.3, 898.9, 1109.8, 1227.5, 1265.7, 1291.8, 1303.8, 1404.7, 1422.5, 1494.6, 1538.9, 1574.0, 1587.1, 1618.8, 2967.0, 2981.4, 3296.5, 3394.9; UV 35710; ${ }^{1} \mathrm{H}$ NMR (DMSO) 3.655 (m, 4H, morpholine), 3.724 (m, 4H, morpholine), 7.443 (d, 4H, J 8.8, CH2 and $\mathrm{CH}-6$ of $\mathrm{Ar}$ ), 7.706 (d, 4H, J 8.8, $\mathrm{CH}-3$ and $\mathrm{CH}-5$ of $\mathrm{Ar}$ ), 9.390 (bs, $1 \mathrm{H}, \mathrm{NH}) ;{ }^{13} \mathrm{C}$ NMR (DMSO) $43.47\left(\mathrm{CH}_{2}-\mathrm{N}\right), 65.98\left(\mathrm{CH}_{2}-\mathrm{O}\right), 113.41\left(\mathrm{C}_{\text {quat }}, \mathrm{CH}-4\right.$ of $\left.\mathrm{Ar}\right), 121.85(\mathrm{CH}-2$ and $\mathrm{CH}-6$ of $\mathrm{Ar}), 131.14$ ( $\mathrm{CH}-3$ and $\mathrm{CH}-5$ of $\mathrm{Ar}), 139.47\left(C_{\text {quat }}, \mathrm{CH}-1\right.$ of $\left.\mathrm{Ar}\right), 163.90\left(C_{\text {quat }} \mathrm{NH}\right), 164.59$ $\left(C_{\text {quat }}-\mathrm{N}\right) ; \mathrm{MS}(\mathrm{EI}+) \mathrm{m} / \mathrm{z} 506\left(\mathrm{M}^{+}, 100\right), 504\left(\mathrm{M}^{+}, 51\right), 475(58), 473$ (27), 461 (67), 459 (32), 449 (57), 447 (36), 427 (13), 425 (14), 420 (21), 418 (11), 378 (15), 307 (16), 305 (13), 224 (24), 222 (23), 198 (27), 196 (24), 184 (10), 171 (13), 157 (21), 155 (18), 144 (15), 142 (15), 118 (16), 90 (21), 86 (7), 76 (13), 74 (9), 69 (4), 63 (8), 56 (14).

Melamine 16. Flash chromatography $\left(\mathrm{CH}_{2} \mathrm{Cl}_{2}: \mathrm{MeOH} 100: 1\right)$, $\mathrm{R}_{\mathrm{f}} 0.34 ;$ m.p. $330-331^{\circ} \mathrm{C}$; IR 545.8, 806.0, 835.2, 898.7, 1107.9, 1171.7, 1233.1, 1271.4, 1314.2, 1399.7, 1413.7, 1506.1, 1536.8, 1585.8, 1627.2, 2217.9, 2863.8, 2987.0, 3106.4, 3219.8, 3286.7, 3341.1; UV 32260; ${ }^{1} \mathrm{H}$ NMR (DMSO) 3.677 (m, 4H, morpholine), 3.760 (m, 4H, morpholine), 7.738 (d, 4H, J 8.8, CH2 and $\mathrm{CH}-6$ of Ar), 7.950 (d, 4H, J 8.8, $\mathrm{CH}-3$ and $\mathrm{CH}-5$ of Ar), 9.858 (bs, $2 \mathrm{H}, \mathrm{NH}) ;{ }^{13} \mathrm{C}$ NMR (DMSO) $43.51\left(\mathrm{CH}_{2}-\mathrm{N}\right), 65.86\left(\mathrm{CH}_{2}-\mathrm{O}\right), 103.16\left(C_{\text {quat }}, \mathrm{CH}-4\right.$ of $\left.\mathrm{Ar}\right), 119.30\left(C_{\text {quat }}, \mathrm{CN}\right), 119.52$ ( $\mathrm{CH}-2$ and $\mathrm{CH}-6$ of $\mathrm{Ar}), 132.88\left(\mathrm{CH}-3\right.$ and $\mathrm{CH}-5$ of Ar), 144.36 ( $C_{\text {quat }}, \mathrm{CH}-1$ of Ar), 163.85 $\left(C_{\text {quat }}-\mathrm{NH}\right), 164.44\left(C_{\text {quat }} \mathrm{N}\right)$; MS (EI+) m/z $398\left(\mathrm{M}^{+}, 100\right), 383(15), 367(91), 353(81), 341$ (82), 312 (40), 285 (20), 270 (29), 252 (14), 224 (9), 184 (188), 169 (42), 156 (11), 144 (32), 117 (16), 102 (37), 90 (12), 86 (9), 69 (7), 56 (13).

Melamine 17. Flash chromatography $\left(\mathrm{CH}_{2} \mathrm{Cl}_{2}: \mathrm{MeOH}: \mathrm{NH}_{4} \mathrm{OH}\right.$ 100:1:0.1), $\mathrm{R}_{\mathrm{f}}$ 0.53; m.p. 248$251^{\circ} \mathrm{C}$; IR 479.2, 740.6, 809.1, 854.9, 1115.1, 1227.7, 1268.8, 1291.1, 1366.6, 1411.9, 1496.8, 1514.5, 1557.6, 1582.9, 2875.1, 2894.4, 2947.8, 3052.8, 3295.6; UV 38460, 33330; ${ }^{1} \mathrm{H}$ NMR ( $\mathrm{CDCl}_{3}$ :DMSO 1:1) 3.771 (m, 4H, morpholine), 3.907 (m, 4H, morpholine), 7.374 (m, 4H, CH of naphthyl), 7.514-7.775 (m, 8H, CH of naphthyl), 8.387 (s, 2H, CH-1 of naphthyl), 8.980 (bs, 
$1 \mathrm{H}, \mathrm{NH}) ;{ }^{13} \mathrm{C}$ NMR $\left(\mathrm{CDCl}_{3}\right.$ :DMSO 1:1) $42.48\left(\mathrm{CH}_{2}-\mathrm{N}\right), 65.23\left(\mathrm{CH}_{2}-\mathrm{O}\right), 114.72(\mathrm{CH}$ of naphthyl), 120.14 ( $\mathrm{CH}$ of naphthyl), 122.74 ( $\mathrm{CH}$ of naphthyl), 124.75 ( $\mathrm{CH}$ of naphthyl), 125.97 ( $\mathrm{CH}$ of naphthyl), 126.07 ( $\mathrm{CH}$ of, naphthyl), 126.59 ( $\mathrm{CH}$ of naphthyl), 128.15 ( $C_{\text {quat }}$ of naphthyl), 132.56 ( $C_{\text {quat }}$ of naphthyl), 136.32 ( $C_{\text {quat }}$ of naphthyl), $163.09\left(C_{\text {quat }} \mathrm{NH}\right), 163.76$ $\left(C_{\text {quat }}-\mathrm{N}\right)$; MS (EI+) m/z $448\left(\mathrm{M}^{+}, 100\right), 417$ (38), 403 (46), 391 (39), 362 (20), 335 (6), 320 (15), 277 (12), 235 (8), 224 (9), 194 (15), 181 (6), 168 (28), 153 (4), 143 (15), 127 (30), 115 (21), 94 (7), $86(2), 77$ (2), 69 (2), 55 (3).

\section{Acknowledgements}

We thank Bulgarian Science Foundation for the financial support (X-1506).

\section{References and Notes}

1. Zhang, W.; Nowlan III, D. T.; Thomson, L. M.; Lackowski, W.; Simanek, E. J. Am. Chem. Soc. 2001, 123, 8914.

2. Steffensen, M.; Simanek, E. Org. Lett. 2003, 5, 2359.

3. Mason, S. F. Molecular Optical Activity and the Chiral Discriminations; Cambridge University Press: Cambridge, U. K., 1982.

4. Harada, N.; Nakanishi, K. Circular Dichroism Spectroscopy Excision Coupling in Organic Stereochemistry; University Science Books, Oxford University Press: Oxford, U. K., 1983.

5. Iuliano, A.;. Franchi, E; Uccello-Barretta, G.; Salvadori, P. J. Org. Chem. 1998, 63, 8765.

6. Iuliano, A.; Voir, I.; Salvadori, P. J. Org. Chem. 1999, 64, 5754.

7. Hasemann, L. WO 99/54334, 1999.

8. Chatelain, E.; Gabard, B. Photochem. Photobiol. 2001, 74, 401.

9. Herzog, B.; Hüglin, D.; Borsos, E.; Stehlin, A.; Luther, H. Chimia 2004, 58, 554.

10. Georges, M.; Dieter, R.; Helmut, L. EP 0,818,450, 1996.

11. Ulrich, H. EP 0,933,376, 1999.

12. Suhadolnik, J. C.; Smith, A.; Cliff, N.; Evers III, H. J.; Wood, M.; Amone, M.; Renz, W. International Conference on Digital Printing Technologies 2002, 348.

13. Brunet, P.; Simard, M.; Wuest, J. D. J. Am. Chem. Soc. 1997, 119, 2737.

14. Kimizuka, M.; Kawasaki, T.; Hirata, K.; Kunitake, T. J. Am. Chem. Soc. 1998, 120, 4094.

15. Kawasaki, T.; Tokuhiro, M.; Kimizuka, N.; Kunitake, T. J. Am. Chem. Soc. 2001, 123, 6792.

16. Prins, L. J.; Hulst, R.; Timmerman, P.; Reinhoudt, D. N. Chem. Eur. J. 2002, 8, 2288.

17. Thalacker, C.; Wuerthner, F. Adv. Funct. Mater. 2002, 12, 209.

18. Jonkheijm, P.; Hoeben, F. J. M.; Kleppinger, R.; Van Herrikhuyzen, J.; Schenning, A. P. H. J.; Meijer, E. W. J. Am. Chem. Soc. 2003, 125, 15941. 
19. Brunet, P.; Demers, E.; Maris, T.; Enright, G. D.; Wuest, J. D. Angew. Chem. Int. Ed. 2003, $42,5303$.

20. Laliberter, D.; Maris, T.; Sirois, A.; Wuest, J. D. Org. Lett. 2003, 5, 4787.

21. Goldin, A.; Wolpert-Defilippes, M. K. Bull. Cancer 1979, 66, 61.

22. Foster, B. J.; Harding, B. J.; Leyland-Jones, B.; Hoth, D. Cancer Treatment Rev. 1986, 13, 197.

23. Menicagli, R.; Samaritani, S.; Signore, G.; Vaglini, F; Dalla Via, L. J. Med. Chem. 2004, 47, 4649.

24. Sączewski, F.; Bułakowska, A.; Bednarski, P.; Grunert, R. Eur. J. Med. Chem. 2006, 41, 219.

25. Cosman, F.; Lindsay, R. Endocr. Rev. 1999, 20, 418.

26. Henke, B.; Consler, T.; Go, N.; Hale, R.; Hohman, D.; Jones, S.; Lu, A.; Moore, L.; Moore, J.; Orband-Miller, L.; Graham Robinett, R.; Shearin, J.; Spearing, P.; Stewart, E.; Turnbull, P.; Weaver, S.; Williams, S.; Bruce Wisely, G.; Lambert, M. J. Med. Chem. 2002, 45, 5492.

27. Maeda, M.; Iogo, M.; Tsuda, H.; Fujita, H.; Yonemura, Y.; Nakagawa, K.; Endo, Y.; Sasaki, T. Anti-Cancer Drug Des. 2000, 15, 217.

28. Kreutzberger, A.; Richter, B. Archiv der Pharmazie 1983, 316, 213.

29. Arenas, J. E.; Cload, S. T.; Fleming, E. S. WO Patent 99/36410, 1999.

30. Ghaib, A.; Ménager, S.; Vérité, P.; Lafont, O. Farmaco 2002, 57, 109.

31. Srinivas, K.; Srinivas, U.; Bhanuprakash, K.; Harakishore, K.; Murthy, U. S. N., Jayathirtha Rao, V. Eur. J. Med. Chem. 2006, 41, 1240.

32. Zhou, Y.; Sun, Z.; Froelich, J. M.; Hermann, T.; Wall, D. Bioorg. Med. Chem. Lett. 2006, 16, 5451.

33. Bhalla, M.; Srivastava, V. K.; Bhalla, T. N.; Shanker, K. Boll. Chim. Farm. 1994, 133, 521.

34. Dianzani, C.; Collino, M.; Gallicchio, M.; Samaritani, S.; Signore, G.; Menicagli, R.; Fantozzi, R. J. Pharm. Pharmacology 2006, 58, 219.

35. Rückle, T.; Schwarz, M. K.; Rommel, C. Nature Rev. 2006, 5, 903.

36. Drabel, W.; Tietjen, K.; Kluth, J. F.; Trebst, A. Angew. Chem. Int. Ed.. 1991, 30, 1621.

37. Omokawa, H.; Tabei, A. Biosci. Biotechnol. Biochem. 2002, 66, 1959.

38. Dinku, W.; Megersa, N.; Raju, V. J. T.; Solomon, T.; Jönsson, J. Å.; Retta, N. Bull. Chem. Soc. Ethiopia 2003, 17, 35.

39. Silverman, F. P.; Petracek, P. D.; Heiman, D. F.; Ju, Z.; Fledderman, C. M.; Warrior, P. J. Agric. Food Chem. 2005, 53, 9769.

40. Desai, N. C.; Bhatt, J. J.; Shah, B. R.; Trivedi, P. B.; Undavia, N. K. Indian J. Exper. Biol. 1996, 34, 584.

41. Ludovici, D. W.; Kavash, R. W.; Kukla, M. J.; Ho, C. Y.; Ye, H.; De Corte, B. L.; Andries, K.; De Béthune, M.-P.; Azijn, H.; Pauwels, R.; Moereels, H. E. L.; Heeres, J.; Koymans, L. M. H.; De Jonge, M. R.; Van Aken, K. J. A.; Daeyaert, F. F. D.; Lewi, P. J.; Das, K.; Arnold, E.; Janssen, P. A. J. Bioorg. Med. Chem. Lett. 2001, 11, 2229.

42. Van Herrewege, Y.; Vanham, G.; Michiels, J.; Fransen, K.; Kestens, L.; Andries, K.; Janssen, P.; Lewi, P. Antimicrob. Agents Chemother. 2004, 48, 3684. 
43. Vzorov, A. N.; Bhattacharyya, D.; Marzilli, L. G.; Compans, R. W. Antiviral Res. 2005, 65, 57.

44. Guillemont, J. E. G.; Pasquier, E. T. J.; Heeres, J.; Hertogs, K.; Bettens, E.; Lewi, P. J.; De Jonge, M. R.; Koymans, L. M. H.; Daeyaert, F. F. D.; Vinkers, H. M.; Arts, F. X. J. H. US Patent 0142571, 2006.

45. Guillemont, J. E. G.; Pasquier, E. T. J.; Heeres, J.; Hertogs, K.; Bettens, E.; Lewi, P. J.; De Jonge, M. R.; Koymans, L. M. H.; Daeyaert, F. F. D.; Vinkers, Janssen, A. J.; H. M.; Arts, F. X. J. H. US Patent 0194804, 2006.

46. Caddick, S. Tetrahedron 1995, 51, 10403.

47. Deshayes, S.; Liagre, M.; Loupy, A.; Luche, J.-L.; Petit, A. Tetrahedron 1999, 55, 10851.

48. Lidstrom, P.; Tierney, J.; Wathey, B.; Westman, J. Tetrahedron 2001, 57, 9225.

49. Kirschning, A.; Monenschein, H.; Wittenberg, R. Angew. Chem. Int. Ed. 2001, 40, 650.

50. Loupy, A. Microwaves in Organic Synthesis, Wiley-VCH: Weinheim, 2002.

51. Kappe, C. O.; Stadler, A. Microwaves in Organic and Medicinal Chemistry, Wiley-VCH: Weinheim, 2005.

52. Tierney, J.; Lidström, P., Eds.; Microwave Assisted Organic Synthesis, Blackwell Publishing: London, 2005.

53. Loupy, A.; Petit, A.; Hamelin, J.; Texier-Boullet, F.; Jacquault, P.; Mathe, D. Synthesis 1998, 1213.

54. Varma, R. S. Green Chem. 1999, 1, 43.

55. Varma, R. S. Pure Appl. Chem. 2001, 73, 193.

56. Varma, R. S. Advances in Green Chemistry: Chemical Syntheses Using Microwave Irradiation, Astra Zeneca Research Foundation, Kavitha Printers: Bangalore, India, 2002.

57. Varma, R. S. Microwave Technology - Chemical Synthesis Application, Kirk-Othmer Encyclopedia of Chemical Technology, J. Wiley \& Sons, Inc.: New York, 2003.

58. Quirke, J. M. E. In Comprehensive Heterocyclic Chemistry, Katritzky, A. R.; Rees, C. W., Eds.; Pergamon Press: Oxford, 1984, Vol. 3, 457.

59. Fries, H. H. Ber. 1886, 19, 2055.

60. Schaefer, F.; Thurston, J.; Dudley, J. J. Am. Chem. Soc. 1951, 73, 2900.

61. Comins, D. L.; O'Connor, S. In Adv. Heterocycl. Chem., Katritzky, R., Ed., Academic Press: New York, 1988, Vol. 44, p 243.

62. Hollink, E.; Simanek, E. E.; Bergbreiter, D. E. Tetrahedron Lett. 2005, 46, 2005.

63. Srinivas, K.; Srinivas, U.; Rao, V. J.; Bhanuprakash, K.; Kishore, K. H.; Murty, U. S. N. Bioorg. Med. Chem. Lett. 2005, 15, 1121.

64. Afonso, C. A. M.; Lourenço, N. M. T.; Rosatella, A. A. Molecules 2006, 11, 81.

65. Sunduru, N.; Agarwal, A.; Katiyar, S. B.; Nishi; Goyal, N.; Gupta, S.; Chauhan, P. M. S. Bioorg. Med. Chem. 2006, 14, 7706.

66. Sha, Y.; Dong, Y. Synth. Commun. 2003, 33, 2599.

67. Almena, I.; Diez-Barra, E.; De la Hoz, A.; Ruiz, J.; Sanchez-Migallon, A. J. Heterocycl. Chem. 1998, 35, 1263. 
68. Díaz-Ortiz, Á.; Elguero, J.; De la Hoz, A.; Jiménez, A.; Moreno, A.; Moreno, S.; SánchezMigallón, A. QSAR \& Combinatorial Science 2005, 24, 649.

69. Kurteva, V.; Afonso, C. Green Chem. 2004, 6, 183.

70. Thurston, J.; Dudley, J.; Kaiser, D.; Hechenbleikner, I.; Schaefer, Fr.; Holm-Hansen, D. J. Am. Chem. Soc. 1951, 73, 2981.

71. Matsuno, T.; Kato, M.; Tsuchida, Y.; Takahashi, M.; Yaguchi, S.; Terada, S. Chem. Pharm. Bull. 1997, 45, 291.

72. Bras, G. I.; Antonov, V. K.; Kurdyumova, K. N. Zh. Obsh. Chim. 1958, 28, 2972.

73. Shibuya, I.; Oishi, A.; Yasumoto, M. Heterocycles 1998, 48, 1659. 